\title{
Two New Funerary Inscriptions from Bursa Museum
}

\author{
Fatma AVCU*
}

After 1993 numerous new inscriptions have been brought to the Archaeological Museum of Bursa. Within the scope of a research project conducted by Prof. Dr. N. Eda Akyürek Şahin and funded by Akdeniz University since 2004, some of them have been published ${ }^{1}$. Two of the new funerary inscriptions are presented below.

\section{No. 1. Epigram for Charmosynos (Fig. 1 a-b)}

Find spot: Unknown. Inv. No.: - ; H.: 47 cm; W.: 59 cm; D.: 9 cm; Lh.: 1,8-2 cm.

Limestone stele. On the shaft of the stele there is a thirteen-line inscription on the tabula ansata. The inscription is enclosed by a frame of ornamentation. A distaff on left side. Ivy leaf at upper right - left side and bottom right side. Scored lines with letters angled Epsilon $E$ and Sigma $\Sigma$. Omega is given as $O \partial$ without underline. And Upsilon is given as $¥$.

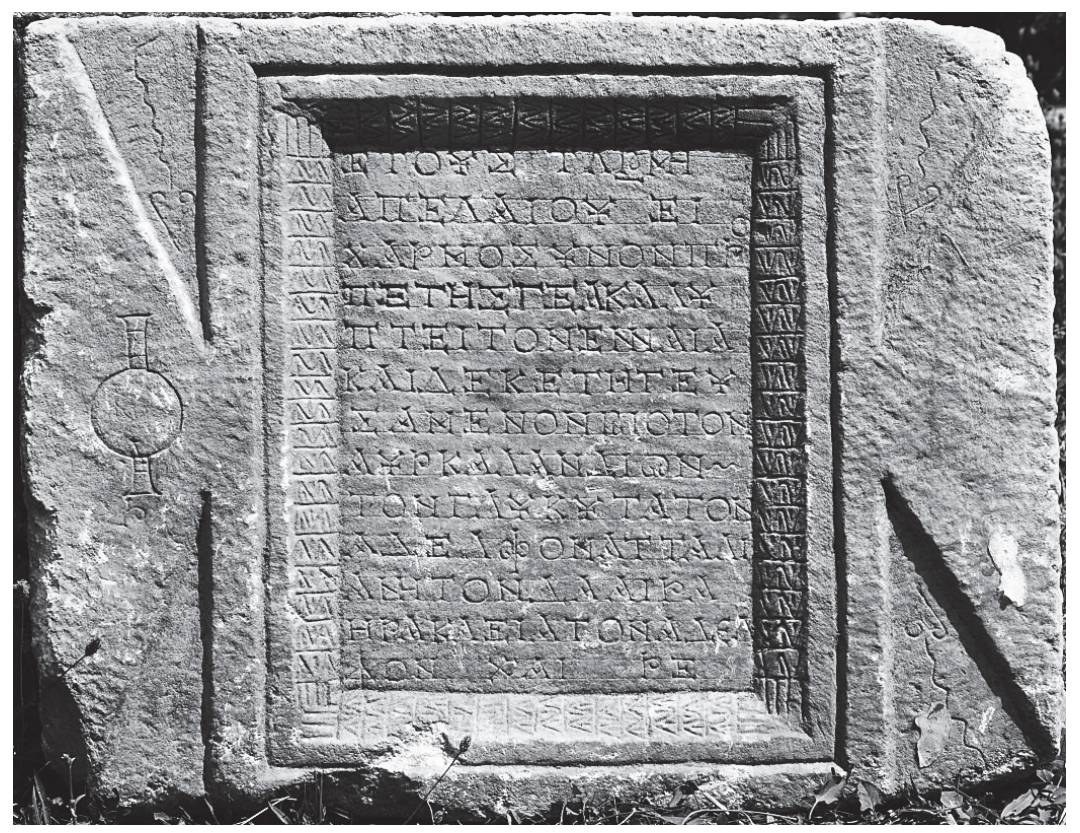

Fig. 1a)

Epigram for Charmosynos

* Arş. Gör. Fatma Avcu, Akdeniz Üniversitesi, Edebiyat Fakültesi, Eskiçağ Dilleri ve Kültürleri Bölümü, Kampüs 07058 Antalya (fatmaavcu@akdeniz.edu.tr).

I am grateful to Prof. Dr. N. Eda Akyürek Şahin who suggested that I publish these inscriptions, Enver Sağır and Ali Sinan Özbey, respectively the ex-director and the current director of the Archaeological Museum of Bursa for their permission to work on these documents. And also I am grateful to Prof. Dr. Johannes Nollé for his remarks concerning the manuscript.

${ }^{1}$ The essential corpus of the inscriptions from Bursa was compiled by Th. Corsten in 1993 (IK 39 and 40). A project for a new corpus of inscriptions in the Archaeological Museum of Bursa is in progress under the direction of Prof. Dr. N. Eda Akyürek Şahin. For subsequent publications see Akyürek Şahin 2008, 9-12; Akyürek Şahin 2010, 271-274; Akyürek Şahin - Onur 2010, 23-39; Akyürek Şahin 2014, 279-283; Uzunoğlu 2015, 397-415; Uzunoğlu - Taşdelen 2015, 37-49. 


\begin{tabular}{|c|c|}
\hline & हैंоטৎ $\tau \lambda \gamma^{\prime}, \mu \eta$. \\
\hline \multirow[t]{2}{*}{2} & 'A $\pi \varepsilon \lambda$ á́ov $\varepsilon \iota^{\prime}$. \\
\hline & 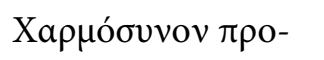 \\
\hline \multirow[t]{2}{*}{4} & 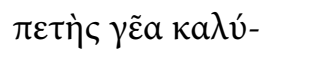 \\
\hline & 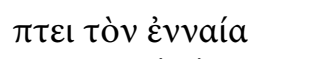 \\
\hline \multirow[t]{2}{*}{6} & 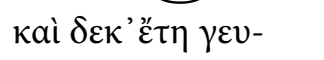 \\
\hline & 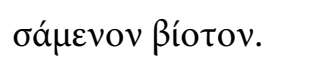 \\
\hline \multirow[t]{2}{*}{8} & 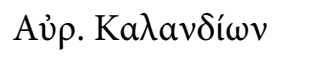 \\
\hline & 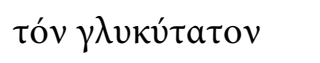 \\
\hline \multirow[t]{2}{*}{10} & 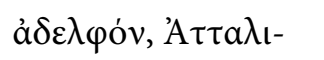 \\
\hline & 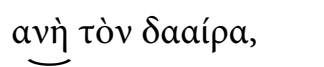 \\
\hline 12 & 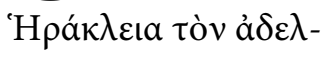 \\
\hline & $\varphi o ́ v$, vac. $\chi \alpha \tilde{l}^{\text {vac. }} \rho \varepsilon$. \\
\hline
\end{tabular}

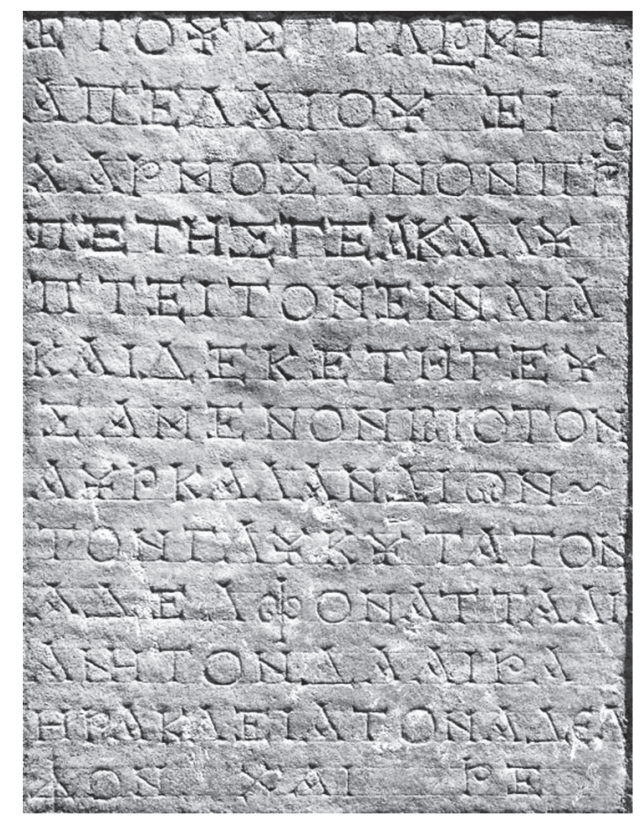

Fig. 1b) Detail of the epigram

In the year 333, on the $15^{\text {th }}$ day of the month Apel(l)aios: Earth covers Charmosynos [our brother?] too early, who tasted life for nineteen years. Aurelius Kalandion (buried) his sweetest brother, Attaliane (buried) her brother-in-law, Herakleia (buried) her brother. Farewell!

L. 1: Sullan Era. $333=248 / 249$ AD.

L. 2: 'A $\pi \varepsilon \lambda \alpha i ́ o v=$ 'A $\pi \varepsilon \lambda \lambda \alpha i ́ o v$.

L. 3-7 Whereas the pentameter of this distich is metrically, but not grammatically correct, as it

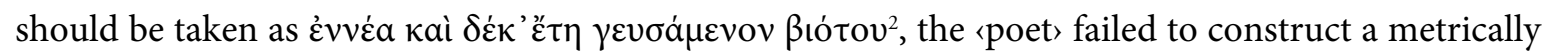

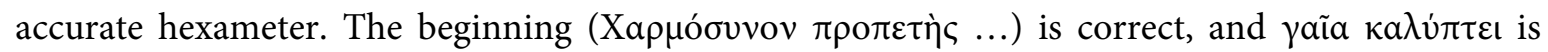

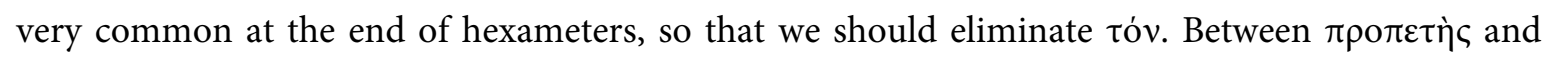

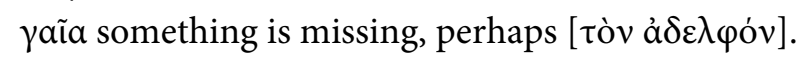

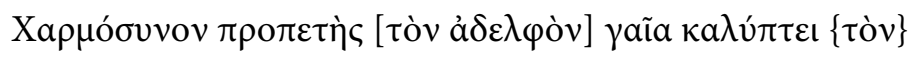

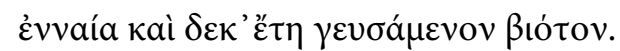

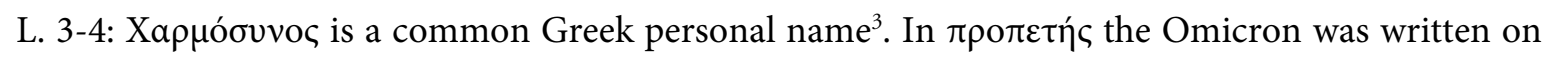
the top of Rho, as there was not enough space for it in this line.

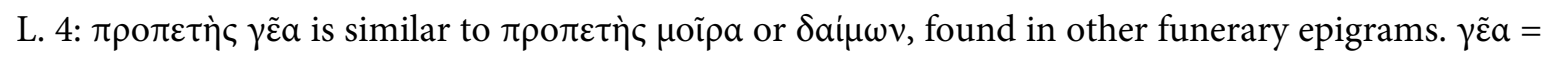
үaĩa. The interchange of al and $\varepsilon$ cf. Gignac 1976, 192.

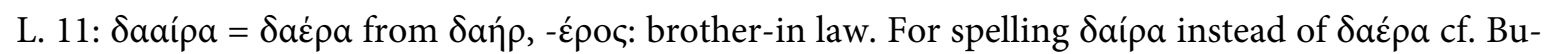
resch $1977,116{ }^{4}$

\footnotetext{
${ }^{2}$ Cf. IPerge 411; IG V/1 1186.

${ }^{3}$ See the volumes of LGPN (I, II A, III A, IV, V A, V B).

${ }^{4}$ For Saípa also cf. TAM V/1 56, 472, 483a and 660.
} 


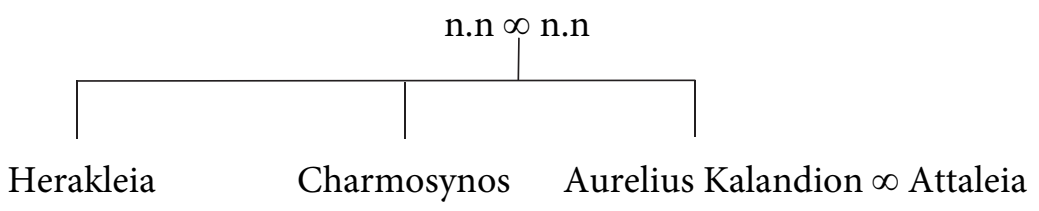

\section{No. 2. Gravestone for Eutychianos (Fig. 2 a-d)}

Find Spot: Unknown. Inv. No.: - ; H.: $47 \mathrm{~cm}$; W.: $59 \mathrm{~cm}$; D.: 7 cm; Lh.: 1,5-2 cm.

Limestone with tabula ansata, broken into four pieces. The inscription is framed by floral ornaments. A perfume bottle was carved on the right side and an ornament (Fig. 2d: a hammer / pickaxe?) on the left side. Beneath the inscription a billhook (falx arboraria ${ }^{5}$ (Fig. 2c), a plough and two zebus (Fig. 2b), probably the ploughing oxen, were incised into the free space of the tabula ${ }^{6}$.

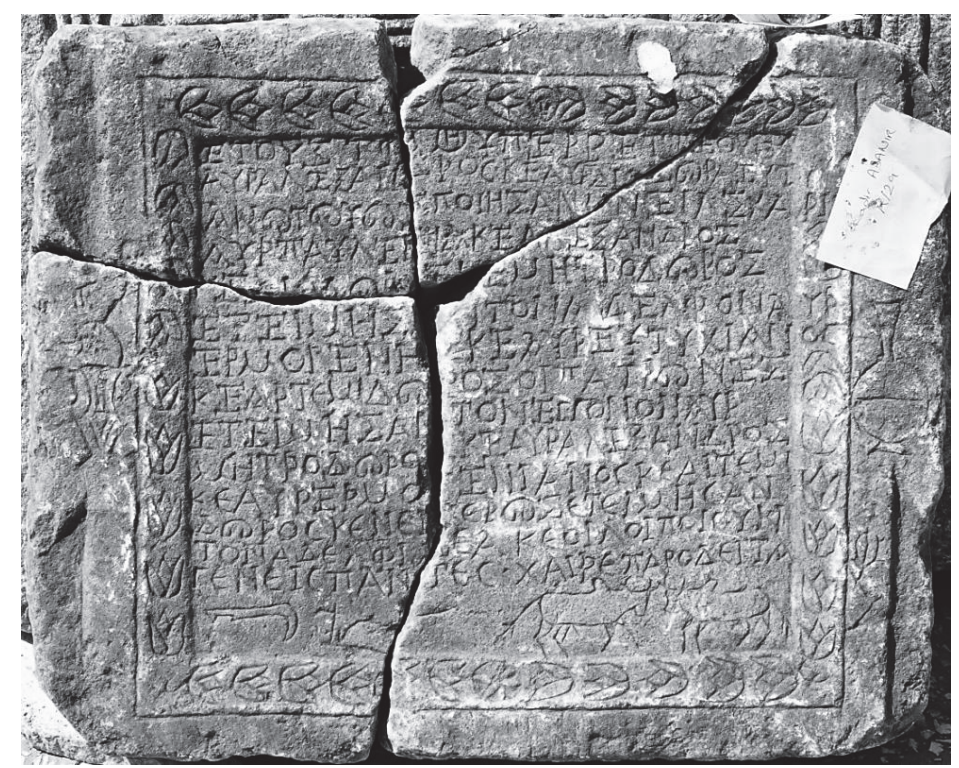

Fig. 2a) Gravestone for Eutychianos

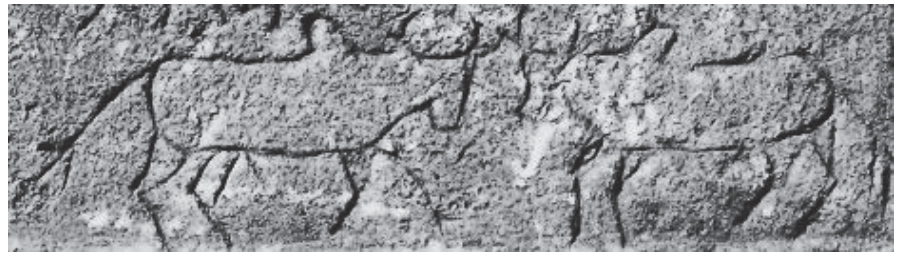

Fig. 2b) The zebus

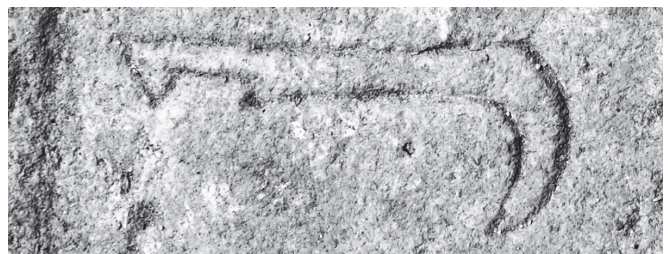

Fig. 2c) The billhook

${ }^{5}$ For falx arboraria, see White 1967, 85-88. Its depiction on the tomb stelae in Prusa ad Olympum and its vicinity is prevalent, cf. Uzunoğlu 2015, 40, fn. 4 (with further references).

${ }^{6}$ For tomb stelae in the northwestern part of Asia Minor see Cremer 1991, 1992. About zebu cf. Pinkwart 1965, 43f; cf. Plin., NH., 8.179; Hrouda 1997, 91-150, esp. 130 “... und unter den Haustieren gibt es den Nachweis für das Zebu, die indische Rasse des Hausrindes. ... aber das in situ-Foto zeigt doch noch die für das Buckelrind charakteristische Gestalt mit den steil aufragenden Hornzapfen und der gewölbten Stirnpartie. Buckelrinder entstanden, wie gesagt, auf dem indischen Subkontinent aus der lokalen Unterart des Auerochsen. Aufgrund dieses einzigen Fundes können wir jedoch nicht sagen, ob Zebus beim Fundort regelmäßig gezüchtet oder nur gelegentlich aus dem Osten eingehandelt wurden. Osteologisch ist das Zebu auch für die Unterstadt in Boğazköy-Hattuša nachgewiesen.”. 


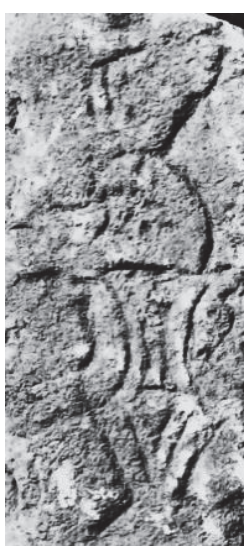

Fig. 2d) $A$

Hammer/ pickaxe?

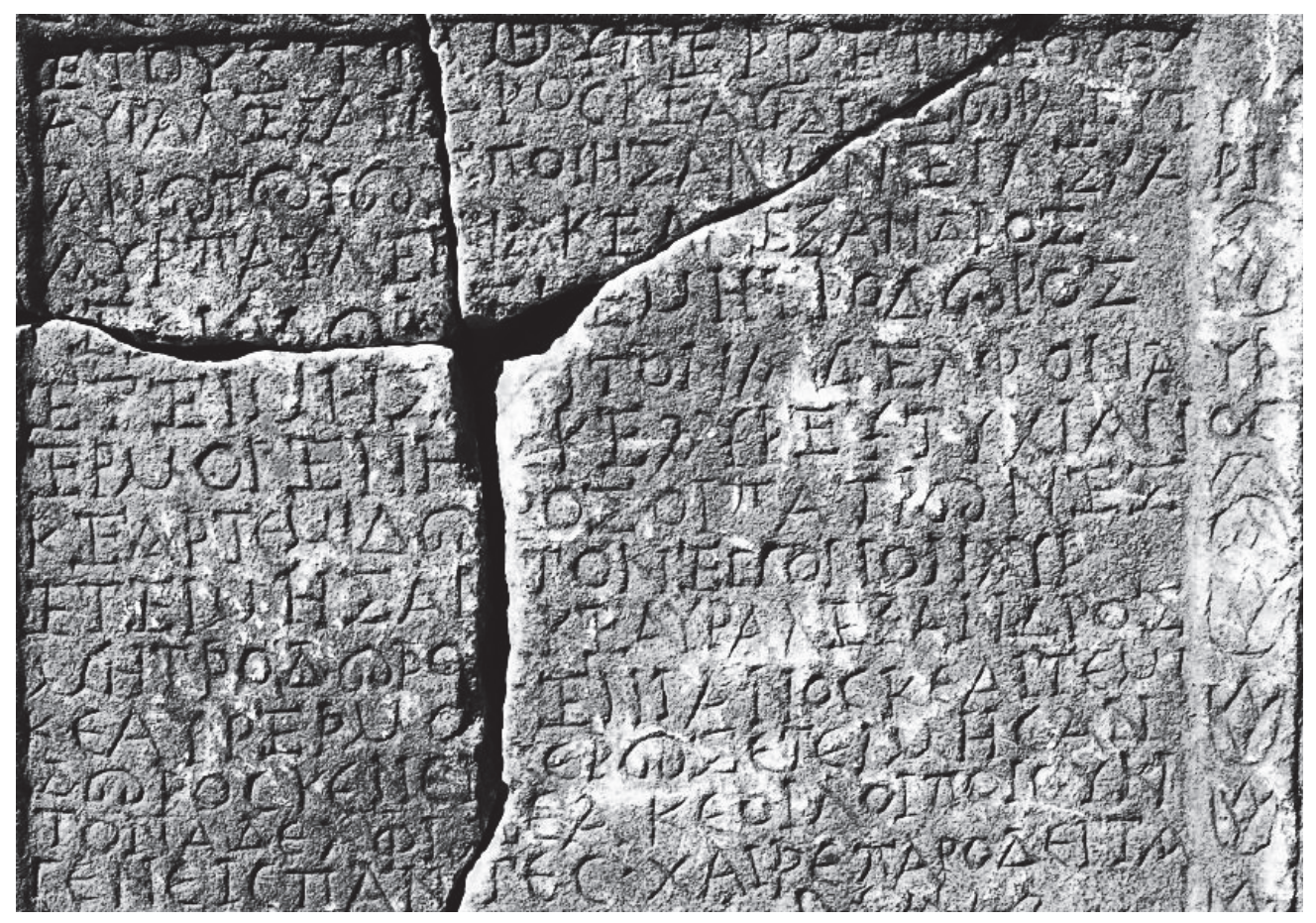

Fig. 2e) The inscription

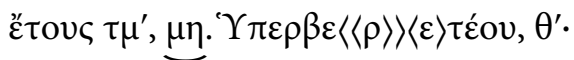

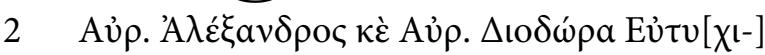

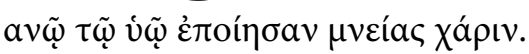

4 Aủ

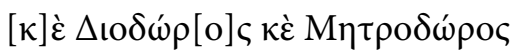

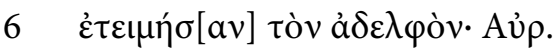

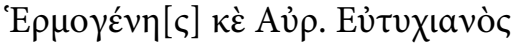

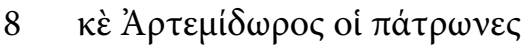

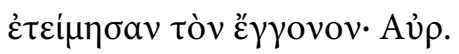

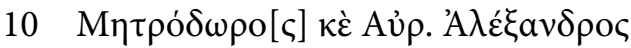

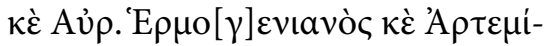

$12 \delta \omega \rho \circ \varsigma \kappa \grave{\varepsilon} \mathrm{N \varepsilon \iota [ \kappa ] \varepsilon ́ \rho \omega \varsigma} \mathrm{\varepsilon ̇ \tau \varepsilon í \mu \eta \sigma \alpha \nu}$

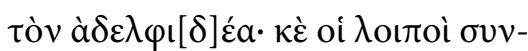

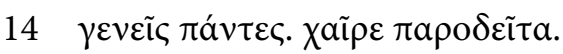

In the year 340, month Hyperberetaios, $9^{\text {th }}$ day. Aurelius Alexandros and Aurelia Diodora made (this grave) for their son Eutychianos in his memory. Aurelia Paulina, Alexandros, Hermodoros and Metrodoros honoured their brother. The paternal uncles Aurelius Hermogenes, Aurelius Eutychianos and Artemidoros honoured their descendant. The maternal uncles Aurelius Metrodoros, Aurelius Alexandros, Aurelius Hermogenianos, Artemidoros and Nikeros honoured their nephew, and all the rest of kinship honoured him. Farewell passenger!

L. 1: Sullan Era. 255/256 A.D.

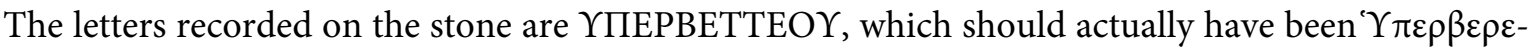

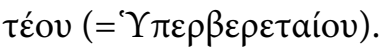

L. 3: $\dot{v} \tilde{\omega}=v i \tilde{\omega}$.

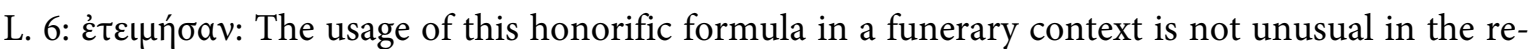
gion of Bithynia. According to an inscription preserved in the Bursa Museum and published recently by Uzunoğlu and Taşdelen $(2014,42-43$, no. 5), there are even examples in which the grave 
owner was honoured with a golden wreath " $\chi \rho v \sigma \tilde{\omega} \sigma \tau \varepsilon \varphi a ́ v \omega$ " by his threptoi, threptai and freedmen.

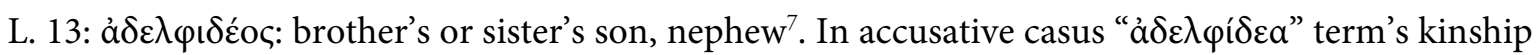
connection is not clear. It was recorded a limited number in inscriptions which do not give a clear explanation for the kinship connection ${ }^{8}$. In such a case it should have connection to the maternal uncle. There are also in the nominative casus "ả $\delta \varepsilon \lambda \varphi ı \delta$ oṽ $\varsigma$ ", and "ả $\delta \varepsilon \lambda \varphi ı \delta \tilde{\eta}$ " versions which mean nephew?.

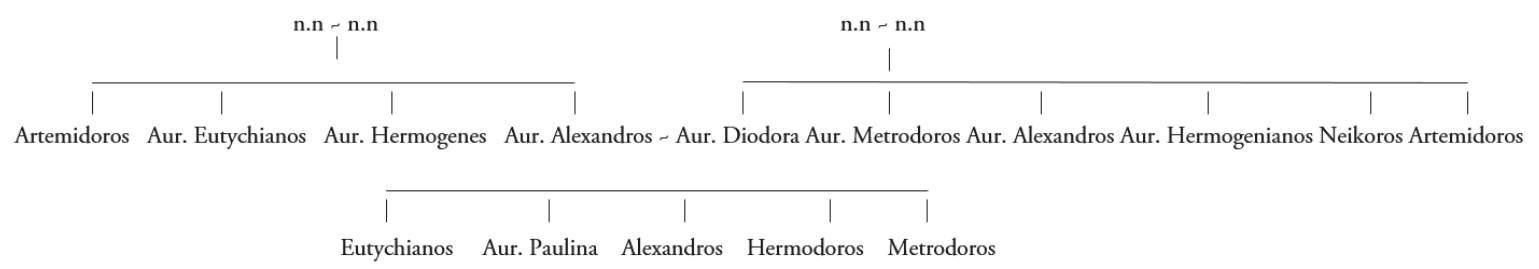

Fig. 3) Possible family ties of the individuals in no. 2

\section{Bibliography}

Akyürek Şahin - Onur 2010

Akyürek Şahin 2008

Akyürek Şahin 2010

Akyürek Şahin 2014

Buresch 1977

Corsten 1990

Cremer 1991

Cremer 1992
N. E. Akyürek Şahin - F. Onur, Neue Grabinschriften im Museum von Bursa, Gephyra 7, 2010, 23-39.

N. E. Akyürek Şahin, Ein Epigramm aus Nikaia: Klage einer Mutter über den frühen Tod ihrer Kinder, in: E. Winter (ed.), Vom Euphrat bis zum Bosporus. Kleinasien in der Antike. Festschrift für Elmar Schwertheim zum 65. Geburtstag (Asia Minor Studien 65), Bonn 2008, 10-12.

N. E. Akyürek Şahin, Zwei neue Inschriften für Hosios kai Dikaios, Olba 18, 2010, 267-280.

N. E. Akyürek Şahin, Bursa Müzesi'nde Klasik Dönem'e Ait Bir Epigram, in: Ç. Akşit et al. (ed.), In memoriam Filiz Öktem, Ankara 2014, 279-283.

K. Buresch, Aus Lydien Epigraphisch-geographische Reisefrüchte, Hildesheim-New York 1977.

T. Corsten, Neue Grabstelen mit Totenmahlreliefs aus der Gegend von Prusa ad Olympum, EA 16, 1990, 91-108.

M. L. Cremer, Hellenistisch-römische Grabstelen im nordwestlichen Kleinasien 1. Mysien, Bonn 1991.

M. L. Cremer, Hellenistisch-römische Grabstelen im nordwestli-

\footnotetext{
${ }^{7}$ See LSJ, s.v. ả $\delta \varepsilon \lambda \varphi ı$ हैoç.

${ }^{8}$ There are only three inscriptions which contain in the accusative casus $\alpha \dot{\alpha} \delta \lambda \varphi \hat{i} \delta \varepsilon \alpha$ term. One is from Asia Minor. The other ones are from Delos and Lindos. For these inscriptions see TAM V/1 707; ID 1993; Lindos II 455.

${ }^{9}$ These terms are attested frequently. For some examples from Asia Minor see TAM V/1 702; SEG XL 1099.
} 
Gignac 1976

Hrouda 1997

Pinkwart 1965

Uzunoğlu - Taşdelen 2014

Uzunoğlu 2015

White 1967

Zgusta 1964 chen Kleinasien 2. Bithynien, Bonn 1992.

F. T. Gignac, A Grammar of the Greek Papyri of the Roman and Byzantine Periods (I-II), Milano 1976.

B. Hrouda, Vorläufiger Bericht über die Ausgrabungsergebnisse auf dem Sirkeli Höyük/Südtürkei von 1992-1996, IstMitt 47, 1997, 91-150.

D. Pinkwart, Das Relief des Archelaos von Priene und die «Musen des Philiskos», Kallmünz 1965.

H. Uzunoğlu - E. Taşdelen, Some New Inscriptions from the Museum of Bursa, Gephyra 11, 2014, 37-49.

H. Uzunoğlu, Bursa Müzesi’nden Ölü Ziyafeti Sahneli Yeni Mezar Stelleri, Olba 23, 2015, 397-415.

K. D. White, Agricultural Implements of the Roman World, Cambridge 1967.

L. Zgusta, Kleinasiatische Personennamen, Prague 1964.

\section{Bursa Müzesi'nden İki Yeni Mezar Yazıtı \\ Özet}

Bu yazıda Bursa Müzesi’nden iki adet mezar yazıtı tanıtılmaktadır. Eserlerin buluntu yerleri bilinmemektedir. 1 numaralı yazıt Kharmosynos için kardeşleri ve yengesi tarafından yaptırılan mezara ait bir şiirdir. 2 numaralı yazıt ise Eutykhianos için ailesi tarafından yaptırılan bir mezarın yazıtıdır.

Yazıtların çevirileri şöyledir:

No. 1: 333 yıl, Apellaios ayının 15. günü. Erkenden örtüyor toprak, hayatın tadını 19 yıl boyunca çıkarmış olan Kharmosynos'un üstünü. Aurelius Kalandion pek tatlı kardeşini, Attaliane kayınbiraderini ve Herakleia kardeşini gömdü. Selam olsun!

No. 2: 340 yılı, Hyperbattaios ayını 9. günü. Aurelius Aleksandros ve Aurelia Diodora oğulları Eutykhianos için anısı vesilesiyle (bu mezarı) yaptırdılar. Aurelia Paulina, Aleksandros, Hermodoros ve Metrodoros kardeşlerini, amcalar Aurelius Hermogenes, Aurelius Eutykhianos ve Artemidoros varislerini, Aurelius Metrodoros, Aurelius Aleksandros, Aurelius Hermogenianos, Artemidoros ve Neikeros yeğenlerini ve geri kalan tüm akrabalar onurlandırdılar. Selam ey yoldan geçen!

Anahtar Sözcükler: Bursa; Bithynia; mezar yazıtları; epigram.

\section{Two New Funerary Inscriptions from Bursa Museum}

\section{Abstract}

This paper presents 2 funerary inscriptions recorded during epigraphic research in the depot and the garden of the Archeological Museum of Bursa. These inscriptions' findspots are unknown. No. 1 is an epigram on a tabula ansata for Charmosynos, erected by his siblings Aurelius Kalandion, Attaleia and Herakleia, No. 2 is a grave stone on a tabula ansata for Eutychianos, erected by his family. Both inscriptions are carved in ancient Greek.

Keywords: Bursa; Bithynia; funerary inscriptions; epigram. 